\title{
Species richness, diversity and human activities in an elevation gradient of a high-ecosystem in Lagunas Huascoaltinas, Atacama Region, Chile
}

\author{
Doris Sanhueza, Marcelo Miranda, Miguel Gómez, and Cristian Bonacic \\ Facultad de Agronomía e Ingeniería Forestal, Pontificia Universidad Católica de Chile, Casilla 306-22, \\ Santiago, Chile
}

\begin{abstract}
D. Sanhueza, M. Miranda, M. Gómez, and C. Bonacic. 2009. Species richness, diversity and human activities in an elevation gradient, a high-ecosystem, Lagunas Huascoaltinas, Atacama Region, Chile. Cien. Inv. Agr. 36(3):411-424. The relationship between species richness, diversity and grazing frequency along an altitudinal gradient (1900-3400 m) of an Andean ecosystem indicates that there is an intense human pressure on vegetation use. To identify the vascular flora and its conservation, 20 sites were sampled in two visits during 2006. We identified 79 taxa, including $62.03 \%$ native species, $22.78 \%$ adventitious and $8.86 \%$ endemic (the remaining $6.33 \%$ was identified only at the genus level). Some genera were underrepresented. We also observed latitudinal limits (Alstremeria andina), monotypic genera (Geoffroea, Kurzamra, Phragmites, Tessaria and Salix) and monogeneric families (Buddlejaceae, Ephedraceae, Equisetaceae, Malesherbiaceae, Salicaceae and Oxalidaceae). Moreover, we found differences in the species distribution patterns during periods of grazing use and identified statistically significant differences in the species richness $(\mathrm{p}<0.001)$, diversity $(\mathrm{p}$ $=0.010)$ and grazing frequency $(\mathrm{p}=0.047)$.
\end{abstract}

Key words: Altitudinal gradients, species richness, vegetal diversity, human pressure, Andean wetlands ecosystems.

\section{Introduction}

The High Andean eco-Region, which lies between the Copiapó River and the Osorno volcano, corresponds to an altitudinal strip that spans the tree vegetation limit to the higher vegetation limit. It is generally found in river basins that are separated by high mountain chains, which allows for the development of endemisms (Hoffmann et al., 1998).

Received 29 December 2008. Accepted 25 May 2009.

Corresponding author: dpsanhue@puc.cl.
Lagunas Huascoaltinas (284ㄴ $\mathrm{S}$; $\left.69^{\circ} 53^{\prime} \mathrm{W}\right)$, the site under study, is located in the Sub-Andean floor or puna (2.700 and $3.500 \mathrm{~m}$ high), where the most common species are bush-like (Adesmia hystrix, Ephedra breana, Viviania marifolia), and Jarava chrysophylla is the most common graminea (Squeo et al., 1994; Hoffmann et al., 1998). In 1996, the Corporación Nacional Forestal de Chile (CONAF) declared the areas of Laguna Grande, Laguna Chica and Laguna Valeriana to be priority sites. The National Environmental Commission of Chile (Comisión Nacional de Medio Ambiente de Chile, CONAMA), through biodiversity conservation programs and priority site identifi- 
cation, established this zone as a Category of Some Conservation Priority in 2003. Nevertheless, there have not yet been studies evaluating the effect of anthropic use on the sector flora. This priority site represents a transitional zone between the tropical and Mediterranean pluviometric regimes (Di Castri and Hajek, 1976), where ecological and historical processes have allowed the evolution of a characteristic mixed biota (Morrone, 2004).

Squeo et al. (1994) characterized the High Andean vegetation around $30^{\circ} \mathrm{S}$ in the Doña Ana mountain chain in the Region of Coquimbo. This study provided a global characterization of the flora and vegetation of the desert Andes. Arroyo et al. $(1988,1984)$ described the flora in the area of Lagunas Huascoaltinas, recording the habitat and new altitudinal ranges of the species. In this site, as in other places in Chile, the anthropic activities have progressively and irreversibly degraded the biological communities, leading to the loss of soil covers and making it more difficult for these sites to be used (Arroyo et al., 1988; Primack et al., 2001; Villagrán and Castro, 2003).

Goats are exotic mammals that have received attention from scientists because of their negative impacts on the natural ecosystems in which they have been introduced (Alvarez-Romero and Medellín, 2005). The Laguna Grande sector (Figure 1) is visited during the summer pastures by breeder who extensively rely on goats, which consume the vegetation of the zone. People also use the vegetal resources to build houses and pens and to extract medicinal plants. The domestic goats considerably affect the herbs and bushes, leading to deforestation and the reduction of resources used by the native fauna (Jaksic, 1998).

The objective of this work was to determine the relationship between variable richness, the Shannon diversity index and the number of grazed species, while considering anthropic use and the type of existing habitat in the studied altitudinal gradient.

\section{Materials and methods}

Area of study

The work was carried out along an altitudinal gradient from the town of Junta de Valeriano $\left(28^{\circ} 53^{\prime} \mathrm{S} ; 70^{\circ} 02^{\prime} \mathrm{W}\right)$ to Laguna Grande $\left(28^{\circ}\right.$ $\left.43 \mathrm{~S} ; 69^{\circ} 54^{\prime} \mathrm{W}\right)$. This region is approximately 1900 to $3400 \mathrm{~m}$ high and lies in the Andean chain of the Third Region of Atacama, Chile (Figure 1).

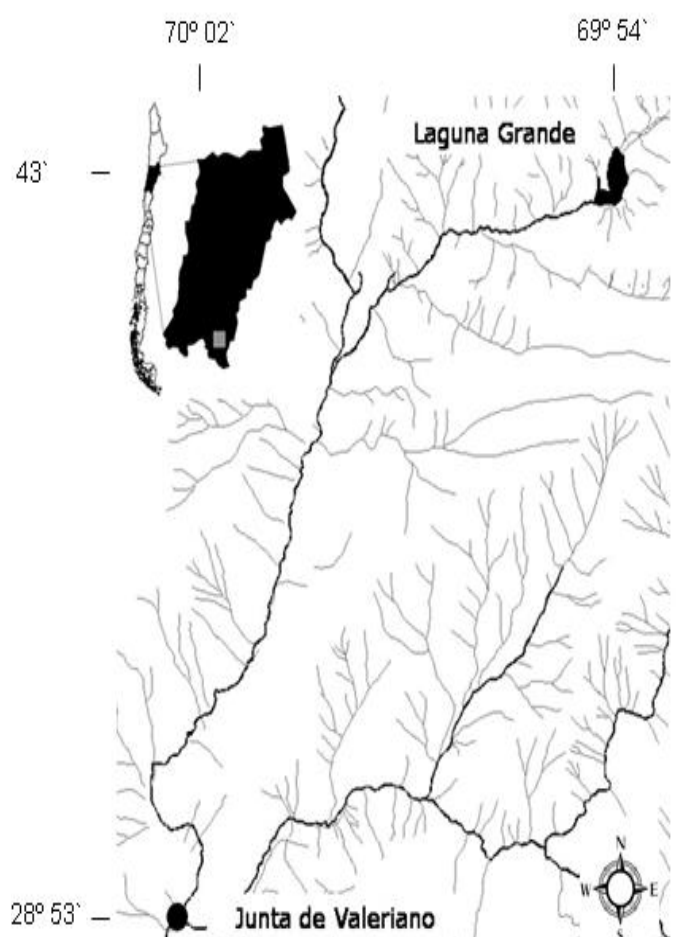

Figure 1.Map of the studied area, "Lagunas Huascoaltinas", Atacama Region, Chile.

This geographical area is in the Region of the High Andean Steppe of the arid and semiarid zone of the Andes Mountain Chain (Gajardo, 1994). According to Di Castri and Hajek (1976), the site under study is located in a desert climate 
zone and has winter rains that provide the area with some features of a Mediterranean climate. Therefore, the antitropical variant of the area indicates a transition towards the zone of the Mediterranean climate, with a warm thermal regime and a mean annual temperature $\geq 21^{\circ} \mathrm{C}$. (Luebert and Pliscoff, 2006). The mean precipitation accrued over 30 years (1961-1990) in the Vallenar aerodrome $\left(28^{\circ} 35^{\prime} \mathrm{S}\right.$; $70^{\circ} 46^{\prime} \mathrm{W}$; 469 $\mathrm{m}$ high) was $31.6 \mathrm{~mm}$ per year.

\section{Methodology}

Two expeditions to the area under study were made in February-March and November-December of 2006. During these expeditions, we sampled 20 points, which were established with three 50 meter long parallel linear transects separated by $50 \mathrm{~m}$. These transects were placed from the Cazadero river shore, and the vegetal communities were sampled on the river shores. The expedition in February-March corresponded to the summer season, after summer pasture, when there is intensive use of the vegetation in the high zones of the altitudinal gradient. The second expedition in November-December corresponded to the winter season, before the summer pasture and when the vegetation use is concentrated in the low zones of the gradient. This cattle activity allowed us to divide the gradient into two sectors: the winter use zone (intervened during the whole year), located between 1900 and $2600 \mathrm{~m}$ high, and the summer use zone (only intervened during the summer pastures), located in the high part of the gradient between 2700 and $3400 \mathrm{~m}$ high.

To generate a floral list of the area under study, all of the vegetal species that were found were sampled and photographed in their habitat for further identification.

In each transect, we recorded: (1) the richness of species, corresponding to the total number of species within the $50 \mathrm{~m}$ long transects, and (2) the abundance and frequency of grazed species (action made by animals as they cut and eat vegetation), which corresponded to all of the species that touched the transect every $5 \mathrm{~m}$. The grazed species were determined through the presence or absence of irregular cuts on their leaves or stems.

\section{Statistical analysis}

This information allowed us to estimate the Shannon biodiversity index $(\mathrm{H})$ as:

$$
H=\sum_{i=1}^{S}\left(\frac{n_{i}}{n} * \ln \left(\frac{n_{i}}{n}\right)\right.
$$

where, $n$ is the number sample individuals, $n_{i}$ is the number of individuals belonging to the $i^{\text {th }}$ species and $S$ is the number of species in the sample.

Subsequently, the richness results, the Shannon biodiversity index and the frequency of grazed species were compared, considering two ranges of anthropic use $\left(\mathrm{n}_{\text {winter }}=18 ; \mathrm{n}_{\text {summer }}=22\right)$ and two types of habitat $\left(\mathrm{n}_{\text {meadows }}=10 ; \mathrm{n}_{\text {hillsides }}=10\right)$, through the non-parametric test of Kruskal-Wallis multiple ranges analysis (differences among multiple independent groups). The relationship between the number of grazed species and the Shannon biodiversity index for every range of use and type of habitat was determined using a simple linear regression model.

\section{Results}

During both seasons, 79 taxa of the vascular flora were identified (74 at the species level; 5 at the genus level) (Table 1). During the first expedition, 64 taxa were recorded, and 53 were recorded during the second expedition. These taxa include 66 genus and 40 families in total. The most frequent species were: $A$. hystrix, Buddleja suaveolens, Cortaderia rudiuscula, E. breana, Fabiana imbricata, Haplopappus baylahuen, J. chrysophylla, Schinus poligama, Senecio an- 
Table 1. Flora inventory, frequency of species and frequency grazing in an elevation gradient during sampling over two seasons in the Lagunas Huascoaltinas, Atacama Region, Chile, 2006.

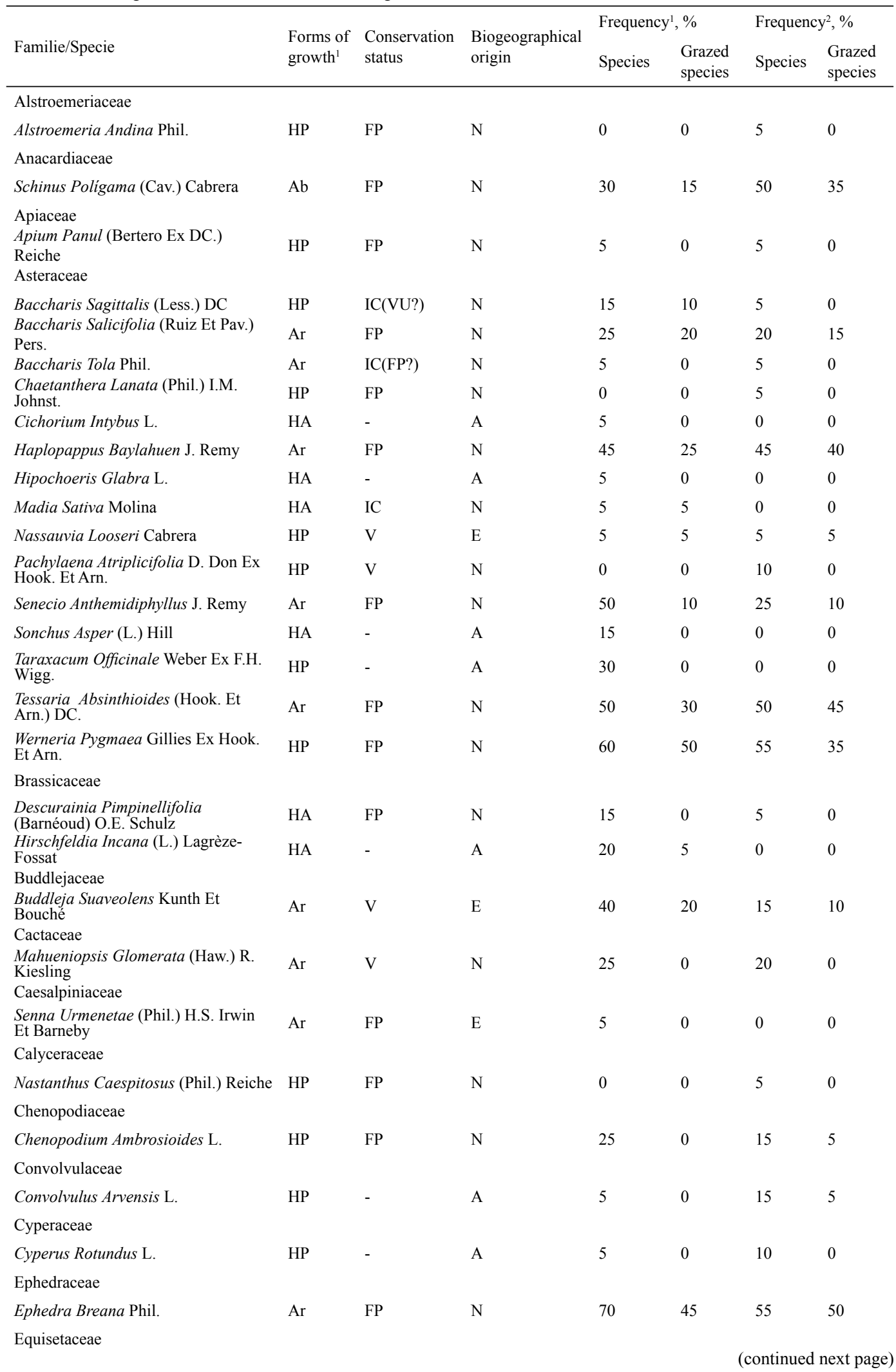


Equisetum Bogotense Kunth

Fabaceae

Adesmia Aegiceras Phil.

Adesmia Echinus K. Presl

Adesmia Hystrix Phil.

Adesmia Sp. 1

Adesmia Sp. 2

Astragalus Bustillosii Clos

Geoffroea Decorticans (Gillies Ex Hook. Et Arn) Burkart

Medicago Lupulina L.

Medicago Sativa L.

Geraniaceae

Erodium Cicutarium (L.) L`Hér. Ex

Aiton

Geranium Core-Core Steud.

Poaceae

Cortaderia Rudiuscula Stapf

Distichlis Sp.

Festuca Sp.

Jarava Chrysophylla (E. Desv.)

Peñail.

Muhlenbergia Asperifolia (Nees Et Meyen Ex Trin.) Parodi

Phragmites $\mathrm{Sp}$.

Iridaceae

Sisyrinchium Iridifolium Kunth

Juncaceae

Juncus Arcticus Willd.

Labiatae

Kurzamra Pulchella (Clos) Kuntze Mentha Piperita L.

Mentha Suaveolens Ehrh.

Linaceae

Linum Macraei Benth.

Loasaceae

Loasa Malesherbioides Phil.

Loranthaceae

Tristerix Verticillatus (Ruiz Et Pav.) Barlow Et Wiens

Lythraceae

Lythrum Hyssopifolium L.

Malesherbiaceae

Malesherbia Humilis Poepp.

Malvaceae

Cristaria Andicola Gay

Cristaria Inconspicua F. Phil. Ex Phil. HA

Mimosaceae

Acacia Caven (Molina) Molina

$\mathrm{Ab}$

Nyctaginaceae

Boerhavia Diffusa L.

HP

Oxalidaceae

HP

Ar

Ar

HA

HP

HA

HP

HP

HP

HP

HP

HP

HP

HP

HP

HP

HP

HA

HA

HA
IC(VU?) N

5

0

0

$\begin{array}{lll}\text { Ar } & \text { FP } & \text { N }\end{array}$

Ar FP N

$\mathrm{Ar} \quad \mathrm{IC}(\mathrm{FP}$ ?) $\mathrm{E}$

HP FP N

$\mathrm{Ab} \quad \mathrm{V} \quad \mathrm{N}$

IC(FP?)

A

A

$\begin{array}{llll}0 & 0 & 5 & 0 \\ 0 & 0 & 5 & 0 \\ 40 & 35 & 45 & 25 \\ 20 & 5 & 25 & 15 \\ 5 & 0 & 5 & 0 \\ 0 & 0 & 5 & 0 \\ 5 & 0 & 5 & 5 \\ 25 & 5 & 5 & 0 \\ 15 & 0 & 0 & 0\end{array}$

HP FP N

HP FP N

FP

$\mathrm{N}$

40

15

FP

N

25

FP

IC(FP?)

FP

$\mathrm{N}$

N

A

A

A

FP

N

HP

FP

FP

$\mathrm{N}$

$\mathrm{N}$

N

20

10

20

15

FP

N

5

0

0

0 


\begin{tabular}{|c|c|c|c|c|c|c|c|}
\hline $\begin{array}{l}\text { Oxalis Compacta Gillies Ex Hook. } \\
\text { Et Arn. } \\
\text { Plantaginaceae }\end{array}$ & HP & $\mathrm{IC}(\mathrm{FP} ?)$ & $\mathrm{N}$ & 5 & 0 & 0 & 0 \\
\hline Plantago Hispidula Ruiz Et Pav. & HA & FP & $\mathrm{E}$ & 10 & 0 & 0 & 0 \\
\hline Plantago Lanceolata $\mathrm{L}$. & $\mathrm{HP}$ & - & A & 5 & 5 & 10 & 5 \\
\hline $\begin{array}{l}\text { Plantago Pachyneura Steud. } \\
\text { Polygonaceae }\end{array}$ & $\mathrm{HP}$ & $\mathrm{FP}$ & $\mathrm{N}$ & 20 & 10 & 0 & 0 \\
\hline Polygonum Aviculare L. & $\mathrm{HP}$ & - & A & 10 & 0 & 0 & 0 \\
\hline $\begin{array}{l}\text { Rumex Longifolius DC. } \\
\text { Portulacaceae }\end{array}$ & HP & - & A & 5 & 0 & 0 & 0 \\
\hline $\begin{array}{l}\text { Calandrinia Affinis Gillies Ex Arn. } \\
\text { Ranunculaceae }\end{array}$ & HP & FP & $\mathrm{N}$ & 0 & 0 & 5 & 0 \\
\hline Ranunculus Cimbalaria Pursh & HP & $\mathrm{FP}$ & $\mathrm{N}$ & 10 & 5 & 10 & 0 \\
\hline $\begin{array}{l}\text { Rhamnaceae } \\
\text { Discaria Trinervis (Gillies Ex Hook. } \\
\text { Et Arn.) Reiche } \\
\text { Rosaceae }\end{array}$ & $\mathrm{Ar}$ & $\mathrm{V}$ & $\mathrm{N}$ & 35 & 5 & 15 & 0 \\
\hline $\begin{array}{l}\text { Acaena Magellanica (Lam.) Vahl } \\
\text { Salicaceae }\end{array}$ & HP & FP & $\mathrm{N}$ & 25 & 15 & 30 & 0 \\
\hline Salix Babilónica L. & $\mathrm{Ar}$ & - & A & 0 & 0 & 15 & 5 \\
\hline $\begin{array}{l}\text { Salix Humboldtiana Willd. } \\
\text { Saxifragaceae }\end{array}$ & $\mathrm{Ar}$ & $\mathrm{V}$ & $\mathrm{N}$ & 5 & 0 & 0 & 0 \\
\hline $\begin{array}{l}\text { Escallonia Angustifolia K. Presl } \\
\text { Scrophulariaceae }\end{array}$ & $\mathrm{Ar}$ & FP & $\mathrm{N}$ & 5 & 5 & 0 & 0 \\
\hline Mimulus Depressus Phil. & HP & FP & $\mathrm{N}$ & 0 & 0 & 5 & 0 \\
\hline $\begin{array}{l}\text { Mimulus Luteus L. } \\
\text { Solanaceae }\end{array}$ & HP & FP & $\mathrm{N}$ & 5 & 0 & 0 & 0 \\
\hline Fabiana Imbricata Ruiz Et Pav. & $\mathrm{Ar}$ & $\mathrm{FP}$ & $\mathrm{N}$ & 55 & 35 & 40 & 30 \\
\hline Lycium Minutifolium J. Remy & $\mathrm{Ar}$ & FP & $\mathrm{E}$ & 5 & 5 & 5 & 0 \\
\hline $\begin{array}{l}\text { Solanum Eleagnifolium Cav. } \\
\text { Vivianiaceae }\end{array}$ & $\mathrm{HP}$ & - & $\mathrm{A}$ & 0 & 0 & 5 & 0 \\
\hline Viviania Marifolia Cav. & $\mathrm{Ar}$ & FP & $\mathrm{N}$ & 20 & 10 & 10 & 10 \\
\hline
\end{tabular}

HP: Perennial herb, HA: Annual herb, Ab: Trees, Ar: Bush, FP: Safe, IC(VU?): Insufficiently known, IC(FP?): Insufficiently known, IC: Insufficiently known, V: Vulnerable, A: Allochtonous, and -: No history.

${ }^{1}$ Sampling summer season, (February-March 2006). ${ }^{2}$ Sampling winter season (November-December 2006).

themidiphyllus, Sisyrinchium iridifolium, Tessaria absinthioides and Werneria pygmaea. The most represented families were Asteraceae (15 species), Fabaceae (9 species) and Poaceae (6 species). The most frequent forms of growth were perennial herb (41) and bush (22).

According to their biogeographical origin, the species identified were grouped into 56 native or autochthonous species, from which seven are endemic to the Region, 18 species are alochthonous or introduced. Five taxa were identified at the genus level. Seventeen species were identified with problems of conservation. The most frequent native or autochthonous species in both seasons were $C$. rudiuscula $(60-65 \%)$, E. breana (70-55\%), F. imbricata (55-40\%), J. chrysophylla (80-65\%), S. anthemidiphyllus (5025\%), S. iridifolium (40-75\%), T. absinthioides (50-50\%) and W. pygmaea (60-55\%) (Squeo et al., 2008).

In addition to the species with problems of conservation (Squeo et al., 2008), Alstroemeria andina Phil., represents the North latitudinal limit for the species. Four monotypical genera (Geoffroea, Kurzamra, Phragmites and Tessaria) and five monogeneric families (Buddlejaceae, Ephedraceae, Equisetaceae, Malesherbiaceae and Oxilidaceae) were scarcely represented.

The index of biodiversity showed average values of $1.46 \pm 0.47$ during the summer season 
and $1.43 \pm 0.47$ in the winter season, without significant differences between seasons regarding biodiversity (Kruskal-Wallis, $\mathrm{p}=0.7$ ). In the summer season, the most frequently grazed species were $W$. pygmaea $(50 \%)$, and in the winter they were C. rudiuscula (55\%); E. breana (50\%) and $J$. chrysophylla (60\%) (Table 1).

The distribution of the species richness through the altitudinal gradient in the meadows and hillsides in the summer season showed a concentrated core of species close to the town Junta de Valeriano (Figure 1), which lies between 2000$2800 \mathrm{~m}$ above sea level (a.s.1.). Low values for the index of biodiversity were observed in both seasons around Laguna Grande (3200-3400 m

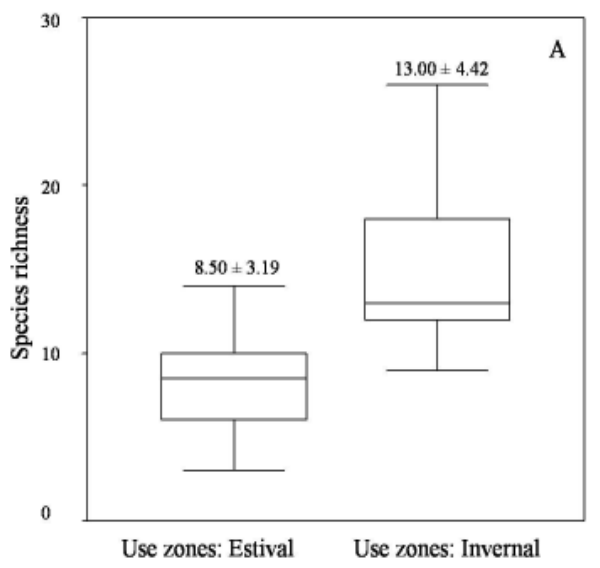

a.s.1.). A higher number of grazed species were found in large meadows during the summer season (2000-2200 and 2700-3000 m a.s.1.); a higher number of grazed species were mainly associated with hillsides in the winter season (2200, 2600 and $3300 \mathrm{~m}$ a.s.1.). The KruskalWallis test identified significant differences in the three variables (richness, index of biodiversity and number of grazed species, Figure 2) grouped in zones of summer and winter use; all of them present higher values in winter use, richness $13.00 \pm 4.42(p=0.000)$, biodiversity $1.73 \pm 0.30(\mathrm{p}=0.010)$ and the number of grazed species $6.00 \pm 2.59(p=0.047)$. There were not significant differences in the type of habitat.
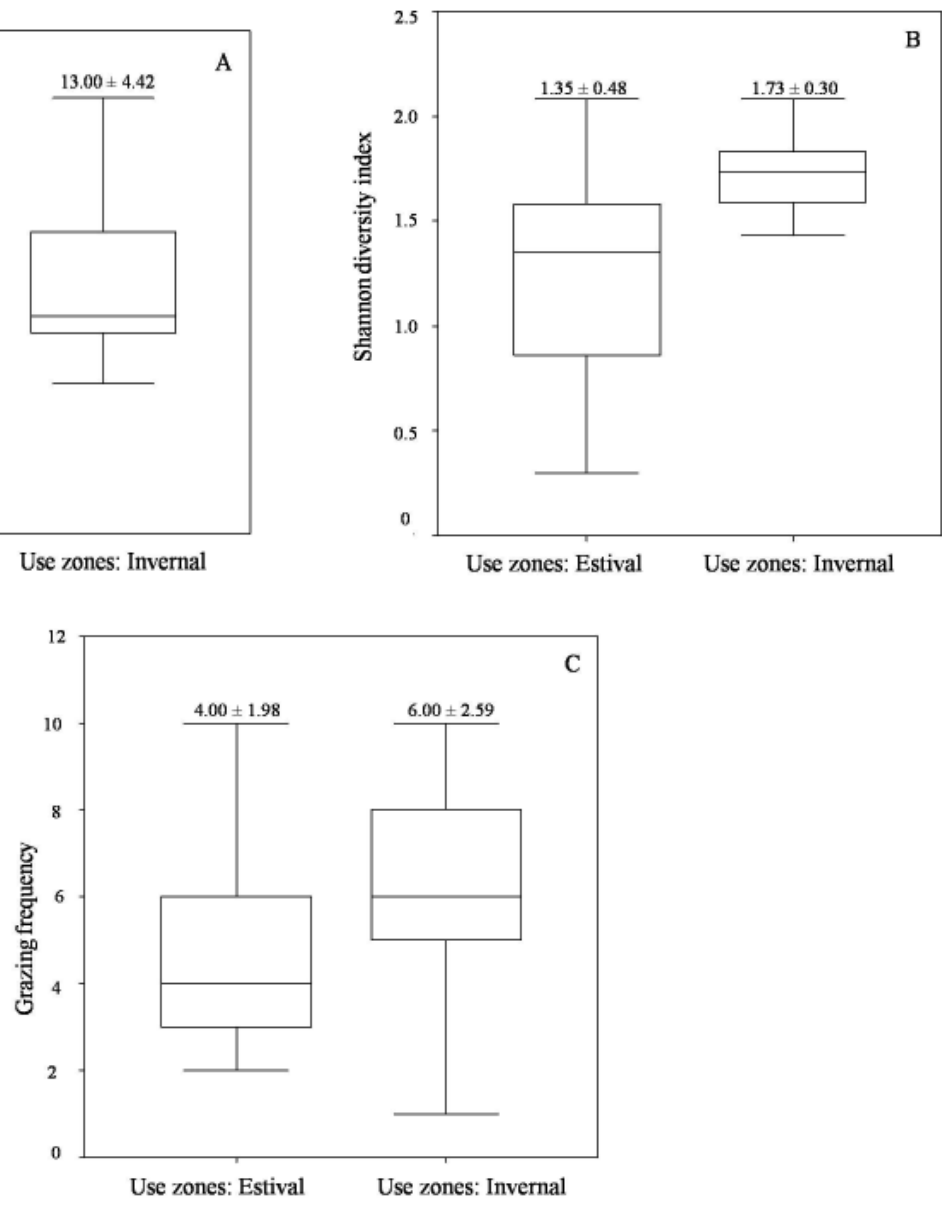

Figure 2. Box plot of (A) the species richness variable, (B) the diversity, and (C) the grazing frequency in a period of grazing use in an elevation gradient. 
The relationship between the number of grazed species and the index of biodiversity is presented in Figure 3. During winter use, we confirmed that small changes in the index of biodiversity are associated with changes in the number of grazed species, which is observed in the slope of $y=7.56 x-6.39, \mathrm{R}^{2}=0.69$ (where $y$ represents the number of grazed species, and $x$ the index of biodiversity). A different behavior was observed during summer use, where the slope between the number of grazed species and the index of biodiversity is lower $y=2.94 x+0.94$, $\mathrm{R}^{2}=0.70$ (Figure $3 \mathrm{~A}$ ).
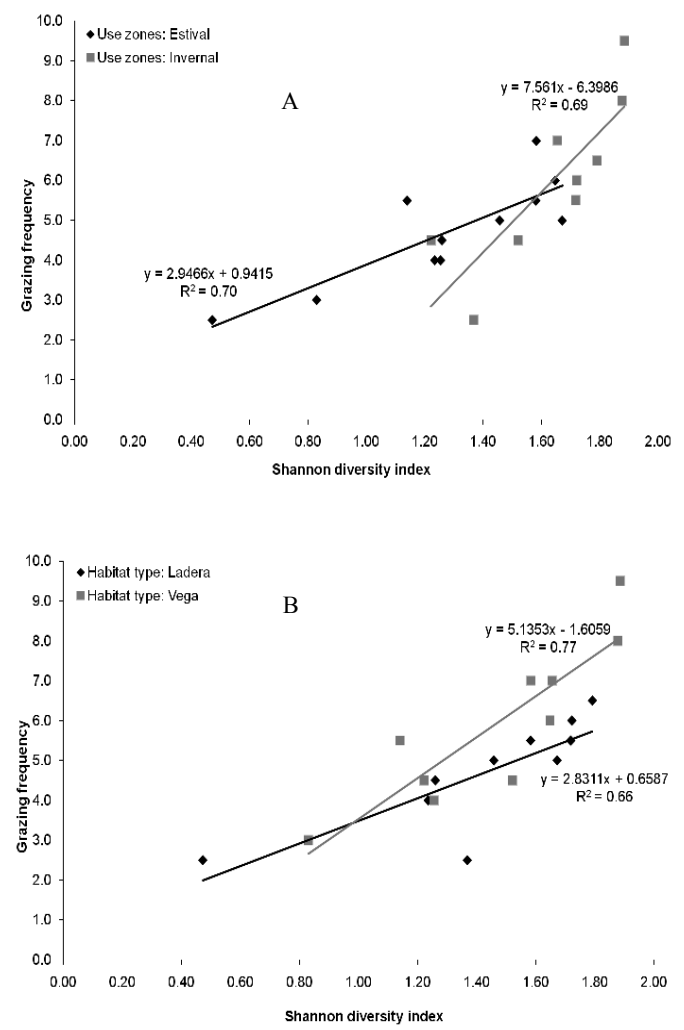

Figure 3. Relationships between the variables of Shannon diversity index and grazing frequency in (A) use zones and (B) habitat type in an elevation gradient.

The relationship between the number of grazed species and the index of biodiversity according to the type of habitat (Figure 3B) showed that small changes in the index of biodiversity in the meadows were associated with higher values of the number of grazed species $(y=5.13 x-1.60$,
$\left.\mathrm{R}^{2}=0.77\right)$. In the hillside habitat, less evident changes were observed, as shown by the lower slope $\left(y=2.83 x+0.65 \mathrm{R}^{2}=0.66\right)$.

\section{Discussion}

Several studies have collected information on floral richness. Cavieres et al. (2000) recorded 103 species in the Alpine zone of the central zone of Chile; Chabot and Billings (1972) recorded 72 species in the Alpine vegetation of Bishop Creek, California; Ferreyra et al. (1998) identified 136 species in the Andes Patagonia of Argentina, and Arroyo et al. (1984) identified 210 species in a altitudinal gradient (Junta de Valeriano, 1900 m, Laguna Grande, 3400 m). The xeric conditions characterizing the Andes in Chile and Argentina (Villagrán et al., 1983) explain, in part, the low richness of species and vegetation with coverage not exceeding $50 \%$. In the present study, 79 taxa were identified, which is a lower richness value than that observed by Arroyo et al. (1984), who made scanning samplings every $50 \mathrm{~m}$. The unequal collection efforts can explain the differences in the number of species observed.

The vascular flora of the area under study had a high value of conservation; species at their North latitudinal limit were recorded in the gradient (Alstroemeria andina) (Arroyo et al., 1984; Squeo et al., 2006). In addition, 66 genera were recorded in the area, four of which were monotypical of the vascular flora of Chile (Geoffroea, Phragmites, Tessaria and Kurzamra), and 40 families were recorded, five of which were monogeneric (Buddlejaceae, Ephedraceae, Equisetaceae, Malesherbiaceae and Oxalidaceae) (Marticorena and Quezada, 1985; Marticorena, 1990; Squeo et al., 2008).

Similar to the study carried out in the sector by Arroyo et al. (1984), in which $51 \%$ of perennial herbs and $23 \%$ of bushes were identified, the most frequent growth forms in the present study were found to be perennial herbs, which are more habitual in meadow zones with higher humidity (51.90\%), while bush-like species $(27.85 \%)$ were found to be more represented in the hillsides (Arroyo et al., 1988). 
Based on the biogeographical origin of the species, $70.89 \%$ of native or autochthonous species were identified, of which $8.86 \%$ were endemic and $22.78 \%$ were allochthonous or introduced. Arroyo et al. (1984) estimated that of the $48.57 \%$ of native species, $20.95 \%$ were endemic and $4.76 \%$ were introduced. An increase in the percentage of introduced species was observed; 12 new records were made in the zone (Hipochoeris glabra, Cichorium intybus, Hirschfeldia incana, Medicago lupulina, Medicago sativa, Mentha suaveolens, Mentha piperita, Lythrum hyssopifolium, Plantago lanceolata, Rumex longifolius and Salix babilónica).

Arroyo et al. (1984) identified 27 species with conservation problems in their 2006 study; 17 of these species were identified, and six corresponded to new records of species with conservation problems (Baccharis tola, C. rudiuscula, G. decorticans, Kurzamra pulchella, Nassauvia looseri and Mahueniopsis glomerata).

A slight decline in the richness of vegetal species in the winter season was observed (summer season $n=64$ and winter season $n=53$ ), possibly due to the intense drought that affected the zone in 2005 and 2006. In addition, the gradient has been strongly affected over the last few decades by intense grazing, the extraction of firewood and medicinal plants and other activities. In a naturally regulated system, we expect the vegetation and native herbivore population to be balanced so that vegetal communities in the ecosystem persist. Overgrazing can upset this balance and lead to a state of degradation, decreasing the herbaceous cover and increasing the risk of erosion (FAO 1968; Morand-Fehr and de Simiane, 1977).

Mazancourt et al. (2000) and Alados et al. (2004) showed that there is an optimal level of grazing that is feasible. This level depends on the recycling efficiency and the capacity of the plant community to recover. The "intermediate disturbance" hypothesis (Connell, 1978; Sousa, 1984; Alados et al., 2004) states that intermediate levels of disturbances actually favor biodiversity, due to the increased competence of ecosystems that are rich in resources (Piggot, 1980; Alados et al., 2004). In semiarid grazing ecosystems, however, irreversible changes to the vegetation occur when the number of herbivores is high, in comparison with natural autoregulated systems (Van de Koppel et al., 2000; Alados et al., 2004).

The presence of domestic cattle, particularly in years of low food availability as occurred in our study sector during 2006, must be included in the analysis of the ecosystem dynamics (Squeo et al., 2006). We and others have found that the species richness declines with grazing, revealing a significant effect of this activity on the species biodiversity (Nai-Bregaglio et al., 2002; Alados et al., 2003). In the arid and semiarid regions of western South America, low seasonal precipitations have limited productivity in most years (Oksanen, 1988). In the region of Atacama, two consecutive dry years occurred, acting in concert with other factors to cause changes in the flora and vegetation of the Region.

Insignificant differences were observed in the index of biodiversity between the two sampling seasons in the present study. Other investigators have shown that extensive livestock influences vegetation, causing a significant decrease of floral biodiversity (Van de Koppel et al., 2000).

As observed in our sector, in the Andes chain in Northern Chile, (Arroyo et al. 1988; Villagrán et al., 1983, 1982, 1981), the species richness was found to decrease by altitude, with the elevation in zones, and with winter precipitation. The distribution of total species richness throughout the altitudinal gradient showed a species concentration in sectors containing large meadows. This concentration of species, associated with a higher percentage of adventitious species, occurred in zones with high anthropic impact. Medicago sativa is an adventitious species that is naturalized in the zone and is present in some sectors of the gradient. Two adventitious species were identified in the areas surrounding Laguna Grande: Cyperus rotundus and Taraxacum officinale. The concentration of species, however, is associated with a higher percentage of endemic species in the sector; in this case, the altitude limits the establishment of other native or adventitious species from lower zones of the gradient (Wilson et al., 1992). 
The spatial distribution of the species is related to the altitudinal variation in the temperature, edaphic conditions, drainage and other factors; floral segregation between altitudinal floors is evident (Luebert and Gajardo, 2000). Higher values of richness and biodiversity index occur in the meadows, zones with more available resources, mainly water from the river courses and underground sources (Villagrán, 2006).

The summer use zone (particularly around Laguna Grande) was characterized by low indexes of biodiversity during both seasons. This area was found to be highly affected by extensive goats and the extraction of firewood and medicinal plants during the summer pastures season. A higher percentage of endemic species was also evident in this zone, one of the important characteristics of the Mediterranean Andes (Gajardo, 1992). A lower slope was observed in the relationship between the index of biodiversity and the number of grazed species in the zone of summer use, where the disturbance is not permanent. Thus, the vegetation has a period of recovery, when some species recover, others emerge and other annual species flower according to their phenology. The disturbance in the zone of winter use is permanent, however, and although there is a higher index of biodiversity, the number of grazed species is higher, as it is the adventitious species.

The grazed species were concentrated mainly in large meadows, where there is a higher availability of biomass for the cattle. In the winter season, however, a higher number of grazed species were associated with the hillsides, where cattle would have better use of vegetation. In addition, a higher slope in the relationship between the index of biodiversity and the number of grazed species in the meadow habitat was evident; higher index values of biodiversity were observed, which were related to a higher number of adventitious species, unlike what was observed in the hillsides, which have a lower availability of resources.

In other semiarid areas, two human activities, namely grazing and extraction of firewood, are known to affect the distribution of vegetation
(Dube and Pickup, 2001; Dembélé et al., 2006). Similar to the present study, in Malí (Nigeria) the grazing has been shown to be limited by the available resources, rivers and underground waters, favoring the formation of zones with abundant vegetation (Dube and Pickup, 2001, Dembélé et al., 2006).

As for the richness and the indexes of biodiversity, the numbers of grazed species in the summer and winter use zones were significantly different across altitudinal gradients; higher values for all the three cases were obtained in the range of winter use (1900-2600 m high). These higher values for richness and index of biodiversity were associated with a higher number of adventitious species in that sector; in addition, browsing is more frequent in the winter use range, and thus it impacts the area for the whole year. Due to the climatic conditions during winter, goats only consume the vegetation up to an altitude of $2600 \mathrm{~m}$. In the gradient studied, the presence of browsing was limited by climatic conditions (winter rains); the higher richness and indexes of biodiversity in the winter range was influenced by the presence of adventitious species.

As described by Meserve et al. (2004), long-term field studies and experimental manipulations are particularly important for understanding the interaction between biotic and abiotic factors in arid and semiarid systems because the population densities are often low and the abiotic events, such as extreme droughts, occur at long temporary scales (between two to seven years). Therefore, it is important to conduct long-term studies and experimental manipulations in the area (exclusions) to identify the biotic and abiotic effects on the flora and vegetation more clearly.

Regarding the native flora of the area under study, we found a scarce representation of species for each genus, the presence of latitudinal limits for some species, genus and monotypical families, and the concentration of endemic vegetal species in places of high anthropic use. The high frequency of browsing concentrated in places characterized by large meadows and the anthropic pressure that has been exerted on this 
ecosystem for decades could be changing the vegetation distribution. This ecosystem could be managed sustainably to ensure the permanence of endemic species and floral biodiversity. The data above indicate the need for the appropriate management of natural resources and the implementation of agricultural practices that are friendly with the environment.

\section{Acknowledgements}

This work was possible thanks to the financial support from the Fondo de Protección Ambiental de CONAMA, project 03-04-2006 and financial support from the Wildlife Trust Alliance and Fauna Australis.

\title{
Resumen
}

\begin{abstract}
D. Sanhueza, M. Miranda, M. Gómez y C. Bonacic. 2009. Relación entre biodiversidad florística e intervención antrópica en un gradiente altitudinal, de un ecosistema altoandino, “Lagunas Huascoaltinas”, Región de Atacama, Chile. Cien. Inv. Agr. 36(3):411-424. Se determinó la relación entre las variables riqueza, índice de biodiversidad y frecuencia de especies ramoneadas, en un gradiente altitudinal (1900-3400 m), el cual forma parte de un ecosistema altoandino, donde ha existido un intenso uso antrópico de la vegetación. Con el objetivo de mejorar la información acerca de la flora vascular de este lugar, se muestrearon 20 sitios en dos visitas a terreno realizadas durante el año 2006. Se identificaron 79 taxa, de los cuales, el 70,89\% correspondió a especies nativas, el 22,78\% a introducidas y el 8,86\% a endémicas (el 6,33\% restante se identificó sólo a nivel genérico). Se reconoció géneros con escasa representación de especies, limites latitudinales (A. andina), géneros monotípicos (Geoffroea, Kurzamra, Phragmites y Tessaria), familias monogenéricas (Buddlejaceae, Ephedraceae, Equisetaceae, Malesherbiaceae y Oxalidaceae). Por otra parte, se determinó diferencias en el patrón de distribución de las especies entre los distintos períodos de uso ganadero, evidenciándose diferencias significativas para las variables riqueza $(\mathrm{p}<0,001)$, índice de biodiversidad $(\mathrm{p}=$ $0,010)$ y frecuencia de especies ramoneadas $(p=0,047)$.
\end{abstract}

Palabras clave: Gradiente altitudinal, riqueza de especies, índice de biodiversidad vegetal, intervención antrópica y ecosistemas andinos de humedad.

\section{References}

Alados, C.L., Y. Puedo, M.L. Giner, T.Navarro, J. Escos, F. Barroso, B. Cabezudo, and J.M. Emlen. 2003. Quantitative characterization of the regressive ecological succession by fractal analysis of plant spatial patterns. Ecological Modelling 163:1-17.

Alados, C., A. ElAich, V. Papanastasis, H. Ozbek, T. Navarro, H. Freitas, M. Vrahnakis, D. Larrosi, and B. Cabezudo. 2004. Change in plant spatial patterns and diversity along the successional gradient of Mediterranean grazing ecosystems. Ecological Modelling 180:523-535.

Alvarez-Romero, J., and R. A. Medellín. 2005. Capra hircus (cabra doméstica). Vertebrados Superiores
Exóticos en México: Diversidad, Distribución y Efectos Potenciales. Instituto de Ecología, Universidad Nacional Autónoma de México. Bases de datos SNIB-CONABIO. Proyecto U020. México. D.F. p. 7.

Arroyo, M.T.K., C. Marticorena, and C. Villagrán. 1984. La flora de la cordillera de los Andes en el área de laguna grande y laguna chica, III Región, Chile. Gayana Botánica 41:3-46.

Arroyo, M.T.K., F.A. Squeo, J.J. Armesto, and C. Villagrán. 1988. Effects of aridity on plant diversity in the northern Chilean Andes: Results of a natural experiment. Annual Missouri Botanical Garden 75:55-78.

Cavieres, L., A. Peñaloza, and M.T.K. Arroyo. 2000. Pisos altitudinales de vegetación en los Andes de Chile central $\left(33^{\circ} \mathrm{S}\right)$. Revista Chilena de Historia 
Natural 2:331-344.

Chabot, B., and W.D. Billings. 1972. Origins and ecology of the sierran alpine flora and vegetation. Ecological Monographs 42:163-199.

Connell, J. 1978. Diversity in tropical rain forests and coral reefs. Science 199:1302-1310.

Dembélé, F., N. Picard, M. Karembé, and P. Birnbaum. 2006. Tree vegetation patterns along a gradient of human disturbance in the Sahelian area of Mali. Journal of Arid Environments 64:284-297.

Dube, O., and G. Pickup. 2001. Effects of rainfall variability and communal and semi-commercial grazing on land cover in southern African rangelands. Climate Research 17:195-208.

Di Castri, F., and E.R. Hajek. 1976. Bioclimatología de Chile. Ediciones Universidad Católica de Chile. Santiago, Chile. 129 p.

FAO. 1968. El pastoreo y los Montes. Estudio de Silvicultura y Productos Forestales, Segunda edición. Roma, Italia. $187 \mathrm{p}$.

Ferreyra, M., A. Cingolani, C. Ezcurra, and D. Bran. 1998. High-Andean vegetation and environmental gradients in northwestern Patagonia, Argentina. Journal of Vegetation Science 9:307-316.

Gajardo, R. 1992. La Vegetación Natural de Chile. Proposición de un Sistema de Clasificación y Representación de la Distribución Geográfica. Departamento de Silvicultura. Universidad de Chile. Santiago, Chile. 52 p.

Gajardo, R. 1994. La Vegetación Natural de Chile, Clasificación y Distribución Geográfica. Primera edición. Editorial Universitaria. Santiago, Chile. $165 \mathrm{p}$.

Hoffmann, A., M.T.K. Arroyo, F. Liberona, M. Muñoz, and J. Watson. 1998. Plantas Alto andinas en la Flora Silvestre de Chile. Primera edición. Fundación Claudio Gay. Santiago, Chile. 281 p.

Jaksic, F. 1998. Vertebrate invaders and their ecological impacts in Chile. Biodiversity and Conservation 7:1427-1445.

Luebert, F. and R. Gajardo. 2000. Vegetación de los Andes áridos del norte de Chile. Lazaroa 21: 111-130.

Luebert, F., and P. Pliscoff. 2006. Sinopsis Bioclimática y Vegetacional de Chile. Primera edición. Editorial Universitaria. Santiago, Chile. $316 \mathrm{pp}$.

Marticorena, C., and M. Quezada, 1985. Catálogo de la flora vascular de Chile. Gayana Botánica 42:5-157.
Marticorena, C. 1990. Contribución a la estadística de la flora vascular de Chile. Gayana Botánica 47:85-113.

Mazancourt, C. and M. Loreau. 2000. Effect of herbivory and plant species replacement on primary production. The American Naturalist 155:735754.

Meserve, P.L., D.A. Kelt, W.B. Milstead, and J.R. Gutierrez. 2004. Una investigación de largo plazo sobre interacciones de factores bióticos y abióticos del ecosistema semiárido del Parque Nacional Bosque Fray Jorge. Páginas 135-159. En: , F.A. Squeo, J.R. Gutiérrez, y I.R. Hernández, (eds.). Historia Natural del Parque Nacional Bosque Fray Jorge. Ediciones Universidad de La Serena, La Serena, Chile.

Morrone, J. 2004. La Zona de Transición Sudamérica: Caracterización y Relevancia Evolutiva. Acta Entomológica Chilena 28:41-50.

Nai-Bregaglio, M., E. Pucheta, and M. Cabido. 2002. El efecto del pastoreo sobre la diversidad florística y estructural en pastizales de montaña del centro de Argentina. Revista Chilena de Historia Natural 75:613-623.

Oksanen, L. 1988. Ecosystem organization: mutualism and cybernetics of plain darwinian struggle for existence. American Naturalist 131:424-444.

Piggot, C.D. 1980. Plant strategies and vegetation processes. The Journal of Ecology 68:704-706.

Primack, R., R. Rozzi, F. Massardo, and P. Feinsinger. 2001. Destrucción y Degradación del Hábitat. Páginas 183-224. En: R. Primack, R. Rozzi, P. Feinsinger, R. Dirzo y F. Massardo (eds.). Fundamentos de Conservación Biológica Perspectivas Latinoamericanas. Primera edición. Fondo de Cultura Económica. México, D.F. México.

Squeo, F.A., R. Osorio, and G. Arancio. 1994. Flora de Los Andes de Coquimbo: Cordillera de Doña Ana. Ediciones de la Universidad de La Serena. La Serena, Chile. 176 p.

Squeo, F., J. Cepeda, N. Olivares, and M.T.K. Arroyo. 2006. Interacciones Ecológicas en la Alta montaña del Valle del Elqui. Geoecología de los Andes Desérticos. Ediciones Universidad de La Serena. La Serena, Chile. p. 69-103.

Squeo, F.A., M.T.K. Arroyo, A. Marticorena, G. Arancio, M. Muñoz-Schick, M. Negritto, G. Rojas, M. Rosas, R. Rodríguez, A.M. Humaña, E. Barrera, and C. Marticorena. 2008. Catálogo de la Flora Vascular de la Región de Atacama. Vol 6. Páginas 97-120. En: Libro Rojo de la Flora Na- 
tiva y de los Sitios Prioritarios para su Conservación: Región Atacama. Ediciones Universidad de La Serena, La Serena, Chile.

Sousa, W. 1984. The role of disturbance in natural communities. Annual Review of Ecologial and Systematics 15:353-391.

Van de Koppel, J., and M. Rietkerk. 2000. Herbivore regulation and irreversible vegetation change in semi-arid grazing systems. Oikos 90:253-260.

Villagrán, C, J.J. Armesto, and M.T.K. Arroyo. 1981. Vegetation in a high Andean transect between Turi and Cerro Leon in northern Chile. Vegetatio 48:3-16.

Villagrán, C, M.T.K. Arroyo, and J.J. Armesto. 1982. Flora y relaciones biogeográficas en los Andes del norte de Chile (18-19 S). Páginas 71-92. En: A. Veloso y E. Bustos (eds.). El Hombre y los Ecosistemas de Montaña. Programa MAB-6.
Villagrán, C., M.T.K. Arroyo, and C. Marticorena. 1983. Efectos de la desertización en la distribución de la flora andina de Chile. Revista Chilena de Historia Natural 56:137-157.

Villagrán, C., and V. Castro. 2003. Ciencia Indígena de Los Andes del Norte de Chile. Primera Edición. Editorial Universitaria. Santiago, Chile. $362 \mathrm{p}$.

Villagrán, C. 2006. Pascua Lama: Amenaza a la Biodiversidad. Oceana, protegiendo los océanos del mundo. Santiago. Oceana. Chile. http://www. oceana.org. (Consultado el 5 de abril, 2007).

Wilson, J.B., G.L. Rapson, M.T. Sykes, A.J. Watkins, and P.A. Williams. 1992. Distribution and climatic correlations of some exotic species along roadsides in South Islands, New Zealand. Journal of Biogeography 19:183-193. 
